\title{
THE NEXT STEP BEYOND EQUITY- THE DECLARATORY ACTION
}

\author{
EDWIN BORCEARD*
}

I

$\mathrm{I}$

T IS a commonplace that the equitable jurisdiction of the Court of Chancery owes its origin (a) to the inflexibility and rigidity of the common law; (b) to the inelasticity of the common law procedure; and (c) to the ineffectiveness or inadequacy of the remedies provided by the common law.

It is not so well known that the same limitations, especially after the merger of law and equity, explain the necessity for relief from the restrictions of equity. Whereas it was intended that equity should be flexible, elastic, and effective in meeting all situations (thus, the Constitution of I7.87 itself assumes that cases in law and equity exhaust the legal reservoir of controversies and remedies), the fact is that equity has with the passage of time become crystallized as an established system, and has proved as inflexible and inelastic in its own field as was the common-law system in its restricted area. This was not the intention of those who founded the system. In the time of Edward $I$ and $I I I^{2}$ it was believed that the chancellor,

* Justus S. Hotchkiss Professor of Law, Yale University.

x Eaton, Handbook of Equity Jurisprudence $\$ 2$ (Throckmorton's ed. I923); Barney, Equity and Its Remedies 3 ( (1915); Clark, Principles of Equity $\S 5$ (1937); Maitland, Equity: A Course of Lectures, Lectures I and II (r936).

Prior to the reign of Edward I, judicial relief in personal actions depended upon whether the plaintiff could fit his case into debt, covenant, trespass, detinue, or replevin. A statute in I 285 ( $\mathrm{r}_{3} \mathrm{Edw}$. I, c. I, $\$ 24$ ) for the purpose of expanding the common law added trespass on the case, from which trover and assumpsit later developed. These remedies were not broadly construed by the common-law judges. The common-law courts at one time themselves attempted a rude equity.

2 This sovereign, about the middle of the fourteenth century, promulgated an ordinance which referred to the Chancellor, or keeper of the Privy Seal, all cases not of the common law deemed "of grace." The jurisdiction thus conferred was not restricted by conventional forms. Says Spence: "From this time suits by petition or bill, without any preliminary writ, became a common course of procedure before the Chancellor as it had been in the council. On the petition or bill being presented, if the case called for extraordinary interference, a writ was issued by command of the Chancellor, but in the name of the King, by which the party complained against was summoned to appear before the Court of Chancery to answer the complaint, and abide by the order of the Court." I Spence, The Equitable Jurisdiction of the Court of Chancery $337-38(1846)$. Mr. Spence approves the establishment of a separate court of chancery where procedure was not limited by rigid forms, since he thinks that the equitable doctrines would have perished but for that fact. He says: "Had not the Clerical Chancellors resisted with effect the introduction of the common law system of pleading, much of the utility of the court would have been destroyed; this is one of the many advantages that resulted from the court 
who already had a common-law jurisdiction and dispensed extraordinary legal remedies, would mould his decrees in accordance with the needs of petitioners, and that the system would always remain fiexible and elastic. But, like all legal systems which lean on remedies, ${ }^{3}$ the system became technical and rigid. By importing this inflexibility and rigidity into equity, notwithstanding its more liberal procedure, the very purpose of creating equity was defeated, as Roscoe Pound so ably shows in one of his notable articles. ${ }^{4}$

Mr. Pound attributes this decadence to five separate operating agencies: (I) the introduction of the common-law theory of binding precedents and resulting case-law into equity; (2) as a consequence, the crystallization of equity, culminating under Lord Eldon; (3) the adoption of equitable actions and equitable defenses in the common law; (4) the conjunction of legal and equitable jurisdiction in the same courts, so general in America; 5 and (5) the abolition of the distinction between law and equity

having been founded by persons who took for their guide the principles of general jurisprudence, and looked only to the attainment of what they considered to be substantial justice." Ibid., at 376 .

3 When equity became a system, stereotyping the grievances it would cure and the relief it would afford, it was not greatly different from beginning suit by writ. We leave aside the subpoena, by which the defendant was summoned to appear in court. The equitable maxim, "where there is a right there is a remedy," had meaning when decrees were moulded to the needs of the petitioner, even though limited by antiquated conceptions of justiciability. But when the equitable remedy became technical and rigid, the maxim lost its beneficent purpose. "Rights" were determined by the criterion whether remedies existed. That made the maxim fairly useless, although historically the rights of the cestui que trust and of the mortgagor are among the most striking effects of equity's expansion under the influence of the principle. Clark, op. cit. supra, note $\mathrm{I}$ I8.

4 Pound, The Decadence of Equity, 5 Col. L. Rev. 20 (I905). Compare the denial of the obsolescence and rigidity of equity in Walsh, Is Equity Decadent?, 22 Minn. L. Rev. 479 (I938). Leonard J. Emmerglick, in his valuable article, A Century of the New Equity, 23 Tex.I. Rev. 244 (I945), deprecates the merger of the two systems, admits the procedure may have benefited though substance has suffered from its effects, and finds that equity-notwithstanding the good administration of individualized justice-profits from the maintenance of separate courts of equity, as in New Jersey. He attributes the rise of new courts, with their specialized jurisdiction, to the need for an individualized justice reflected in the obsolescence of the growth of equity. He maintains that statute has largely taken the place of what should be an expanding equity; consult also Walsh, The Growing Function of Equity in the Development of the Law in 3 Law: A Century of Progress, $1835-1935,1_{39}$ ( $x_{937}$ ).

5 Since the Judicature Act of $I 873,36$ \& 37 Vict., c. 66, and under Rule 2 of the Federal Rules, and in the code states following New York, the distinction between law and equity purports to have been abolished. But by virtue of the Seventh Amendment to the Constitution the federal courts cannot make the merger complete. There is still doubt whether the whole case or the issue needs to be of common law entitling the petitioner to a jury, see Pacific Indemnity Co. v. McDonald, ro7 F. 2d 446 (C.C.A. 9th, I939). In other jurisdictions, also, it is believed that the essential distinctions between legal and equitable rights and remedies still exist. In a few states-Alabama, Delaware, Mississippi, New Jersey, and Tennesseethey still administer the two systems in separate courts. Some lawyers have a vested interest in retaining the technicalities associated with separate jurisdictions. The necessity for bringing 
in procedure and the resulting power of courts to administer both or either in the same action. ${ }^{6}$ Thus he finds that the amalgamation of the two systems is exemplified in the current reports, which disclose four tendencies: (I) the supersession of equitable rules in certain cases by legal rules; ${ }^{7}$ (2) equitable rules or portions of them disappearing; (3) equitable principles becoming hard and fast and legal in their application; (4) equitable rules becoming adopted in such a way as to confuse instead of supplement the legal rules. He then gives examples of each of these tendencies. ${ }^{8}$ Professor Pomeroy feared the effect on equity of the merger of the two systems, and the effort to rigidify equity's remedies and make them "legal," as was happening particularly in the code states. In his preface he says:

Even a partial loss of equity would be a fatal injury to the jurisprudence of a state. So far as equitable rules differ from those of the law, they are confessedly more just and righteous, and their disappearance would be a long step backward in the progress of civilization.9

a declaratory action in the court having jurisdiction often results in gross injustice. A petition involving equitable estoppel was denied by a court of equity, since equitable estoppel is ad-

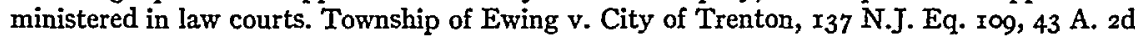
8I3 (r945); see also Springdale Corp. v. Fidelity Union Trust Co., I2r N.J. Law 536, 3 A. 2d 565 (x939), where the plaintiff owned property on which defendant held a mortgage. The defendant had authorized the plaintiff and its president to collect rents for the defendant on termination. The president, having rents in his hands, sued for a declaration as to whether the co-plaintiff corporation or the defendant mortgagee was entitled to receive them. He sued at law. But the Court of Errors, while concluding that the claim of the trust company and the corporation against the president was "legal," considered the president's petition as equitable. Though interpleader would have lain, it would have been impossible to predict the court's conclusion; see also Christiansen v. Local Board 680, I26 N. J. Eq. 508, Io A. 2d I68 (1940). Harsher still is the way in which one Moresh was shunted about by two equity and two legal courts in New Jersey, when all he placed in issue was the question whether his agreement to protect glass against breakage placed him in the insurance business, subject to insurance control. Moresh v. O'Regan, I22 N. J. Eq. 388, 192 Atl. 83I (1937).

In a third series of courts, including many American states, equity and law are administered by the same courts, although the procedure is kept distinct. Clark, op. cit. supra, note $I$, at $\$ 6$; Barney, op. cit. supra, note $I$, at 4 .

${ }^{6}$ Pound, op. cit. supra, note 4 , at 25 . While the crystallization of equity has tended to reduce the area of judicial discretion, we still speak of equitable relief, as of a declaratory judgment, as discretionary subject to rule. The discretion in affording declaratory relief is perhaps wider than that permissible in extending equitable relief generally. In granting declaratory relief the court must be convinced that its decision will settle the controversy and remove the uncertainty which gave rise to the proceeding. It must satisfy itself that the declaration will serve a useful purpose. This is only slightly true in extending equitable relief. Whereas it is an established rule of equity that it is not grantable where there is an adequate remedy at law, no such inquiry is proper on a demand for a declaratory judgment, an alternative remedy grantable in spite of the fact that other remedies are available; see Federal Rules of Civil Procedure, Rule 57 .

7 It was at first thought that equity would prevail over law; the opposite has happened, and this is what Pomeroy so greatly deprecates in his preface.

8 Pound, op. cit. supra, note 4 , at 27.

9 I Pomeroy, Equity Jurisprudence xxv (Symons' ed. r94r). 
The rigidity and inflexibility which have come to surround equitable remedies, while they have helped to expand the jurisdiction and function of administrative courts, are not the only cause of the inadequacy of equitable relief. Had equity retained its pristine flexibility it would readily have perceived that the interests which need protection by declaratory judgment warrant legal protection in equity. Says Pomeroy:

Equitable remedies, on the other hand, are distinguished by their flexibility, their unlimited variety, their adaptability to circumstances, and the natural rules which govern their use. There is in fact no limit to their variety and application; the court of equity has the power of devising its remedy and shaping it so as to fit the changing circumstances of every case and the complex relations of all the parties..$^{\text {To }}$

It is well known that the English statute of $185^{2}$ authorizing the declaratory judgment was a part of the Chancery Procedure Act of that year. In some states, e.g., Florida ${ }^{\mathrm{II}}$ and Massachusetts, ${ }^{\mathrm{I2}}$ the jurisdiction of the declaration was originally confined to equitable cases. It is still so confined in Rhode Island. Its affiliation with equity is therefore unquestionable. But, like the judicial courts which were carved out of the legislature, the declaration has become a separate branch of jurisprudence, independent of equity.

The rigidity of both law and equity is also due to the fact that neither perceived the necessity of relief against insecurity and peril which is afforded to obligors and defendants, not to mention plaintiffs, by the declaratory action. That has not only escaped the limitations historically associated with writs and is a judicial remedy capable of unlimited expansion, which it was hoped equity could administer alone, ${ }^{\mathrm{x}}$ but it affords relief in situations where law or equity fail completely ${ }^{x_{4}}$ The limita-

xo Ibid. § rog. The declaration was incorporated in English law by mere rule of court. Order XXV, rule 5, of the Supreme Court Rules of 1883 (7 Statutory Rules and Orders, 54), and Order LIV A, introduced by the amended Rules of 1893 . See Borchard, Declaratory Judgments 2r8-2I (2d ed. I94I).

rx Lippman v. Shapiro, I5I Fla. 327,9 So. 2 d 636 (rg42). The new Florida act (Fla. Gen'l Acts I943, C. 2I820), one of the most advanced, was dated May 24, I943.

I2 The new Massachusetts act (Mass. Gen'l Acts r945, c. 582) was signed by the Governor on July ro to take effect on November $I$, I945.

${ }_{3}$ I Pomeroy, op. cit. supra, note $9, \S 55$ et seq.

${ }^{4}$ One part of equity consists of primary rights wholly outside the purview of the common law. No question can here arise about the adequacy of legal remedies, because in the nature of the case there can be none such. A second part of equity consists of remedies for the enforcement of legal rights. These are devised by equity as needed, whenever the legal remedy is inadequate. Brief for respondent (i.e., lessee) at 33, Willing v. Chicago Auditorium Ass'n, 277 U.S. 274 ( $x_{928)}$. But when the declaration under the Act of 1852 was limited to cases in which coercive relief would have been possible-the overruled cases were alone cited by Justice

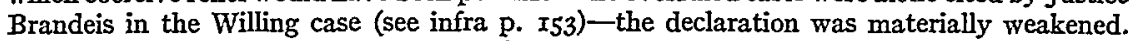
It was only expanded in 1883 when by rule of court it was held to be grantable "whether any 
tions associated with justiciability-and especially the requirement of prior wrong as an accomplished delict-were one of the greatest handicaps to the preventive function of the law and limited the types of cases in which relief could be granted either at law or in equity. The declaratory action, by enlarging the scope of its protective function, dispensing with provable "wrong," and perceiving the necessity for relieving dilemmas insoluble theretofore, has opened up a wide field for judicial relief, while at the same time exposing the historical anachronism of seeking equitable relief under a different system than legal relief. It exposes the impropriety of deriving rights from remedies, and although equitable doctrines and principles were historically designed to afford a remedy wherever there was a claim of right worthy of protection, a right was limited by the technicalities surrounding justiciability.

Under the declaratory action the system operates from rights to remedies and not the other way around. In expanding the conception of "rights" to include the dilemmas of an obligor and a prospective defendant it enables relief to be afforded to parties unprotected theretofore. It must be readily apparent that a debtor has as much interest in denying the unfounded demand of his creditor as the creditor has in asserting his claim upon the debtor. It must be apparent that the defeat and denial of an unfounded claim which disturbs and renders insecure a person's rights, whether of status or property, is as much an interest capable of and in need of judicial protection as the assertion of the claim itself. The use of the criterion of "legal interest" makes it clear either that the conception of a committed "wrong" is too narrow or else that any challenge or cloud upon a person's rights is a "wrong" or disturbance which might, by un-

consequential relief is or could be claimed, or not." Order XXV, rule 5, Supreme Court Rules of 2883 (7 Statutory Rules and Orders 54).

Courts have some difficulty in determining the classification of a declaratory action. Some insist that if not within equity, its grant is subject to equitable principles; others conclude that it has no relation to equity. Some regard it as a special statutory proceeding, sui generis; cf. American Telephone \& Telegraph Co. v. California Bank, 59 Cal. App. 2d 46 I38 P. 2d 49 (1943), as to liberality of construction both as to substance and procedure.

That equitable principles are applied in administration, see Moss v. Moss, II6 P. 2d $65^{\circ}$ (Cal. App. I94x), aff'd 20 Cal. 2d 640, I28 P. 2d 526 (I942); Horwitz v. Stone Boulevard Corp., 37 N.Y.S. $2 \mathrm{~d} 670$ (1942) (declaratory judgment suit by tenantagainstlessor; held, framed in equity, when he had adequate remedy at law); Model Pawnbrokers v. Moss, I87 N.Y Misc. 8I 7, 55 N.Y.S. 2d 73 (1945) (penal legislation challenged; no injunction possible; declaratory judgment sustained); Mutual Life Insurance Co. v. Francis Emory Fitch, Inc., 37 N.Y.S. 2d 965 (1942) (mortgagee against mortgagor; declaratory judgment considered equity); Freiden v. Western Bank \& Trust Co., 72 Ohio App. 47I, 50 N.E. 2d 369 (1943) (land purchaser against vendor to establish no-easement; declaratory judgment not limited to relief beyond law and equity); Liberal Savings \& Loan Co. v. Frankel Realty Co., 64 Ohio App. 97,28 N.E. 2 d 367 (r940), rev'd 137 Ohio St. 489 , 30 N.E. 2 d ror 2 (I940) (classification of declaratory judgment action bysublessee depends on nature of relief sought, legal or equitable). 
settling his security or supposedly vested rights, endow him with the power of invoking judicial relief.

Deprecating the system by which equitable relief had to be sought in ways different from legal, Judge Dillon says:

The separation of what we call equity from law was originally accidental, - or at any rate was unnecessary; and the development of an independent system of equitable rights and remedies is anomalous, and rests upon no principle. The continued existence of these two sets of rights and remedies is not only unnecessary, but its inevitable effect is to make confusion and conflict. The existing diversity of rights and remedies must disappear, and be replaced by a uniform system of rights as well as remedies. $\ldots .$. .

The problem we are discussing is well exemplified by the decision of the Supreme Court in Willing v. Chicago Auditorium Association. ${ }^{16}$ Walter L. Fisher was the chief counsel for the lessees, Charles E. Hughes for the lessors, and the briefs were of the high order of excellence one might expect.

In that case the Chicago Auditorium was an old building erected on property leased for 99 and 198 years, which was paying the stockholders nothing and paying its bonds with great difficulty. The ground became gradually more valuable, as the building deteriorated. In the boom period of the twenties, bankers were prepared to put up $\$ I_{5}, 000,000$ for the erection of a new and modern structure. The lessees thought that under their lease they had the privilege of tearing the old building down and were glad, with bankers' aid, to erect a new building. Approaching the landlords with the offer to erect the new building, they were astonished at the reluctance, then refusal, of the landlords to give their consent without a substantial increase in the rent. The landlords insisted that their consent was necessary and that even a beginning of destruction would cause waste and a forfeiture of the lease, not to speak of damages. The parties thereupon began to litigate, first in Illinois and then in the federal courts, the lessees insisting on their right to tear down the old building, the lessors denying it. What was involved was a construction of the lease.

Judge Wilkerson maintained in the United States District Court that

15 Dillon, Laws and Jurisprudence of England and America 386 (r895), quoted by Pound, op. cit. supra, note 4 , at 23 .

${ }^{{ }^{6}}{ }_{277}$ U.S. 274 (I928), rev'g 20 F. 2 d 837 (C.C.A. 7th, I927), rev'g 8 F. 2 d 998 (N.D. Ill., I925). The three decisions are presented with sufficient completeness in Chafee, Cases on Equitable Remedies 4ro-26 (enl. ed. 1939); cf. Washington-Detroit Theatre Co. v. Moore, 249 Mich. 673,229 N.W. 618 (1930), where the opposite conclusion was reached under a declaratory judgments statute, and the analogous cases of Woodward v. Fox West Coast Theatres, 36 Ariz. 25I, 284 Pac. $35^{\circ}$ (1930), and Girard Trust Co. v. Tremblay Motor Co., 29 I Pa. 507, r40 Atl. 506 (1928). 
equity did not permit him to decide this important question, since a cloud on the title of the lessees, the theory under which it was assumed that complaint began, required a second instrument and did not permit the construction of the lease prior to breach. Judge Wilkerson's opinion fluctuates between the alleged necessity of equity to retain flexibility and his demand that relief be sought under some established head of equity jurisprudence, a subsumption which he did not find present in the Willing case. He says:

It is true that the absence of precedents or novelty in incident presents no obstacle to the exercise of the jurisdiction of a court of equity. It is the distinguishing feature of equity jurisdiction that it will apply settled rules to unusual conditions, and mold its decrees so as to do equity between the parties. But, while this is true, yet the facts of the case must come within some head of equity jurisprudence. When a person brings an equitable action, he must maintain it upon some equitable ground. The great advantage possessed by a court of equity is not so much in its enlarged jurisdiction as in the extent and adaptability of its remedial powers. Before the rule as to inadequacy of remedy at law is applied, some wrong must be shown for which the plaintiff is entitled to redress. In other words, there must be a cause of action, whether resort is had to one forum or the other. A court of equity, by avowing that there is a right, but no remedy known to the law, cannot create a right, in violation of the principles of both law and equity. Before there is a remedy, either at law or in equity, there must be a wrong cognizable in courts of justice under the established principles of law or equity. ..... ${ }^{x 7}$

The Circuit Court of Appeals, realizing the dilemma of the plaintiffs and believing that equity ought to afford relief therefrom, held that one instrument was enough and that the doubt and dispute as to its meaning created the cloud on the plaintiff's right. ${ }^{18}$ They thus reversed the decision of the District Court. On appeal to the United States Supreme Court, Mr. Justice Brandeis held with Judge Wilkerson that the case was not justiciable, ${ }^{\text {,9 }}$ that equity was too well crystallized to afford the relief

${ }^{27} 8$ F. $2 d$ 998, Ioog (N.D. Ill:, I925). Much sounder seems the decision of the Court of Errors and Appeals of New Jersey in Vanderbilt v. Mitchell, 72 N.J. Eq. 9ro, 926, 67 Atl. 97, I03 (I907): "Upon the whole case, we are of the opinion that the Court of Chancery has jurisdiction to afford the complainant ample and complete relief, [to cancel a false birth certifcate]....; that, should the Court of Chancery refuse relief under the circumstances stated in the bill, it would cease to be a court of equity governed by principles of natural justice." See Brief for Respondent 35-36, Willing v. Chicago Auditorium Ass'n, 277 U.S. 274 (I928).

${ }^{18} \mathrm{~A}$ similar liberal view, doubtless forced on the court by the necessity of deciding an otherwise undeterminable question and relieving an intolerable situation, was taken in McArthur v. Hood Rubber Co., 221 Mass. 372, I09 N.E. I62 (I9I5); Rector, etc. v. Rector, etc., I3O App. Div. 166, II4 N.Y. Supp. 623 (rgog), aff'd 201 N.Y. r, 94 N.E. I9I (I9II).

${ }^{\prime}$ "There is not in the bill, or in the evidence, even a suggestion that any of the defendants had ever done anything which hampered the full enjoyment of the present use and occupancy of the demised premises authorized by the leases. There was neither hostile act nor a threat. .... Obviously, mere refusal by a landlord to agree with a tenant as to the meaning and effect of a lease, his mere failure to remove obstacles to the fulfillment of the tenant's desires, is not 
demanded, ${ }^{20}$ and that the ambiguity of a single instrument necessitating construction did not constitute a cloud on title. ${ }^{2 x} \mathrm{He}$ added the further gratuitous statement, quite correct, that what the plaintiffs sought was a declaratory judgment. He then added, unnecessarily and erroneously, "To grant that relief is beyond the power conferred upon the federal judiciary." ${ }_{22}$

Justice Brandeis must have been troubled by the decision because he undertook to emphasize the non-justiciability of the action by construing it not as a dispute but as a unilateral doubt. "The fact that the plaintiff's desires are thwarted by its own doubts, or by the fears of others [the bankers], does not confer a cause of action."23 That it was an active dispute between the parties, that the lending banks awaited the outcome of that dispute, that the term "cause of action" was construed with excessive narrowness, were not emphasized by the learned Justice. In demanding the necessity for a prior "wrong" he emphasized the impracticability of one aspect of both legal and equitable relief, with minor exceptions in equity, in demanding that dishes be broken before judicial relief is obtainable. The benefits of preventive justice seem to have escaped this able and astute judge. ${ }^{24}$

an actionable wrong, either at law or in equity. .... No defendant has wronged the plaintiff or has threatened to do so. ..." 277 U.S. $274,288,29 \circ$ (I928).

Possibly this is designed to show that there was no contested issue between the parties, but a mere academic difference of opinion. But the pleadings show a position most hostile to the lessees. Why, then, refer to prior conversations?

20 "It is true that the plight of which the Association complains cannot be remedied by an action at law. But it does not follow that the Association may have relief in equity in a federal court." Ibid., at $288,289$.

In Piedmont \& Northern Railway Co. v. United States, 280 U.S. 469 (1930), the Supreme Court again took occasion to show that the declaratory judgment lay outside equitable jurisdiction. The railroad claimed that it was an interurban railroad and hence exempt from the interstate commerce requirement of a certificate of public convenience and necessity under paragraph 22 of the Interstate Commerce Act. While the District Court decided the case on the merits, the Supreme Court dismissed for lack of jurisdiction in equity. The railroad thereupon had to build, subjecting itself to penalties and an injunction at the initiative of the Commission. This was considered a more correct procedure, although it took two additional years of litigation and the railroad had to pay penalties as a condition of its right to test the legality of the statute in so far as it applied to the railroad. It was a reflection on the professed inadequacies of equity and an improper view of declaratory procedure.

${ }_{21}$ "The alleged doubt as to plaintiff's right under the leases arises on the face of the instruments by which the plaintiff derives title. Because of that fact, the doubt is not in legal contemplation a cloud, and the bill to remove it as such does not lie." 277 U.S. 274, 288 (Ig28).

2 Ibid., at 289 .

23 Ibid., at 289-90.

24 "Mere refusal" to grant consent under a lease which requires it would seem to be all the "actionable wrong" that anyone could ask, for millions of dollars were placed in jeopardy by that adverse and hostile position. If the law had known an action to compel consent this would 
It is debatable whether courts of equity did not have the power to render declarations from the very beginning. But whether Justice Brandeis meant that the power had not been granted by the legislature, which was correct, or that the power could not be granted by Congress, which was not correct, we shall never know. ${ }^{25}$ At all events, the citations given in support of this statement indicate its error, an error acknowledged in Nashoille, Chattanooga \& St. Louis Ry. v. Wallace, ${ }^{26}$ where Mr. Justice Stone, speaking for a unanimous court, consoled Justice Brandeis by making the assumption that the Willing case involved a hypothetical question. It was not hypothetical but most actual. It was an acknowledgment that courts of equity were unable in I928 to relieve the plight of which the Association complained. The suggestion that declaratory procedure was unknown in 1789 , even if it were true, would not preclude the later introduction of the procedure. The Association was perfectly correct in believing that courts of equity exist for the solution of such problems. They were the victims of the inflexibility and rigidity into which equity had fallen and which Justice Brandeis unconsciously reflected.

II

The hurdle that barred judicial relief in Willing v. Chicago Auditorium Association - the necessity for "wrong" as a condition of a "cause of action" and the inability of equity courts to construe a single living written instrument-has since been successfully climbed by the practically universal acceptance in the United States of the declaratory judgment. ${ }^{27}$

\section{Antrodated Notions of JUstictabitity}

The principal limitations upon equitable relief have been those arising out of antiquated notions of justiciability and the technical requirements of equitable procedure which, as Mr. Pound says, have resulted in the

doubtless have constituted a case or controversy. The term "actionable wrong" seems a little antiquated, reverting to the time when courts of law were deemed only an agency to remedy wrongdoing. The equitable growth of the preventive and declaratory function of judicial power exercised in fact for centuries in Anglo-Saxon courts, should not have passed unnoticed.

${ }_{25}$ Justice Stone in a pithy dissent, adopting the latter view of Justice Brandeis' dictum, criticized the majority Justice for attempting to decide a constitutional issue in advance of any necessity for such decision, contrary to the Court's uniform habit. Congress did pass a declaratory judgments statute in I934, which the Court unanimously sustained in Aetna Life Insurance Co. v. Haworth, 300 U.S. 227 ( 9937 ). They had previously sustained a state act in Nashville, Chattanooga \& St. Louis Ry. v. Wallace, 288 U.S. 249 (r933).

${ }^{26} 288$ U.S. 249 (r933).

${ }^{27}$ Every jurisdiction in the United States, federal and state, has now accepted this procedure except Arkansas, Delaware, Louisiana, Mississippi, and Oklahoma. 
decadence of equity. The first limitation, evident in law cases also, is the peculiar lack of perception of the common law as to what amounts to an impairment of a person's interests and the time or occasion when judicial protection may be invoked. It was long demanded that the plaintiff, in order to have judicial standing, must suffer a "wrong" as a condition of judicial relief-a misconception which gave a false view both to the term "threatened wrong" and judicial power. Some of the more critical students of procedure have long realized the error involved in requiring delict or wrong in every cause of action. ${ }^{28}$ In actions for partition, to declare a marriage void, to quiet title or remove a cloud, to perpetuate testimony, and innumerable others, there is as a rule no delict at all. ${ }^{29}$ The state intervenes, not because there has been a physical infringement of the plaintiff's rights, but because his rights have been denied or disputed or challenged, placing him in danger or jeopardy and causing him detriment or prejudice, thus enabling the court to re-establish and safeguard the right and restore the social order.

It has been discovered by courts that in addition to threat of immediate injury, the placing of the plaintiff in danger of a dispute or challenge of his right also impairs his security and warrants judicial relief. If the status of children as legitimate or illegitimate or of persons as married or unmarried, the title to property, or the powers of the government are placed in uncertainty, both the individual and the state have an interest in removing the uncertainty and settling the issue. The same is true of the parties to a contract, as in Willing v. Chicago Auditorium Association. If the privileges of the parties to a contract or even parties in non-contractual relations are placed in uncertainty, dispute, or danger, the uncertainty warrants removal, the dispute, settlement..$^{30}$ If the legal powers of the government or of officials are challenged, or if an official or a fiduciary is left in

\footnotetext{
${ }^{28}$ Clark, The Code Cause of Action, 33 Yale L. J. 817, 823 et seq. (I924); Bliss, A Treatise upon the Law of Pleading under the Codes of Civil Procedure $\$$ II3 (3d ed. 1894): "The wrong may be done [or the cause of action may arise] by the denial of a right; or by the refusal to respond to an obligation; or it may arise from mere neglect in the performance of a duty; or it may be an affirmative injury." Justice Brandeis relied upon an uncommitted "wrong" as the basis of refusing to consider the Willing case justiciable. We may cite the passage: "... if it were the subject of judicial cognizance, [it] would in form come under a familiar head of equity jurisdiction." Willing v. Chicago Auditorium Ass'n, 277 U.S. 274, 289 (r928). This might indicate that the lack of an established head was regarded as less of an obstacle than the assumed lack of justiciability.
}

29 Clark, op. cit. supra, note 28, at 827; Bliss, op. cit. supra, note 28; Sibley, The Right to and Cause for Action $\S 22$ (IgO2); Chafee, Does Equity Follow the Law of Torts?, 75 U. of Pa. L. Rev. I, I7 et seq. (I926).

${ }^{30}$ Cf. Batchelor v. Newness, ${ }_{45}$ Ohio St. II 5,60 N.E. $2 d$ 685 (I945) (board of trustees of police fund sued $N$ for declaration to determine whether, as claimed, he was entitled to pension credit for pre-police military service). Equity was here difficult to invoke. 
dilemma because of fear of exercising powers which may expose him to personal liability, all parties suffer. In all these cases the state has an interest in removing the uncertainty before disaster has occurred.

We thus have declaratory actions in which the plaintiff claims she is the defendant's wife, which the defendant denies; ${ }^{3 x}$ that the defendant insured is not disabled as claimed, hence the plaintiff company is released from liability on that account; $;^{32}$ that the defendant public official demands certain tax information, from the exaction of which the plaintiff claims immunity; ${ }^{33}$ that the defendant lessee demands the erection of a threestory fireproof building under a lease (the old nonfireproof one having burned), whereas the plaintiff lessor maintains he is privileged to erect a two-story building, the new statutory limit for garages; ${ }^{34}$ that a state statute requires a heavy license fee from billiard parlors in one county only, alleged to be and held unconstitutional; ${ }^{35}$ that the plaintiff is not under a duty to return to the defendant certain moneys paid by the defendant on forged bills of lading, ${ }^{36}$ or any other duty exacted by the defendant creditor or claimant; that the plaintiff claims release from the obligations of a contract for future performance; $;^{37}$ that the plaintiff is privileged without tender or deposit to repay the defendant creditor in Russian rubles instead of British pounds, and thereupon recover the pledged security $;^{38}$ that certain buildings are "temporary" within the meaning of a statute and that the plaintiff public officials are privileged to tear them down. ${ }^{39}$

In these typical cases no wrong or even hostile activity has been committed or threatened - a condition demanded for traditional equitable relief. What we perceive is the existence, of an opposing claim which disturbs the plaintiff's peace of mind and freedom of action, or by raising doubt or insecurity in his legal relations, impairs or jeopardizes his pecuniary or other interests. That suffices to create justiciability. If a will may

${ }^{3 x}$ Henry v. Henry, I04 N.J. Eq. 21, I44 Atl. I8 (r928); Baumann v. Baumann, 224 App. Div. 719 , 229 N.Y. Supp. 833 (r928), aff'd 250 N.Y. 382, I65 N.E. 819 (Ig29).

${ }^{32}$ Aetna Life Ins. Co. v. Haworth, 300 U.S. 227 (1937).

33 Dyson v. Attorney-General, [I9II] I K.B. 4IO, [I9I2] I Ch. 158.

34 Girard Trust Co. v. Tremblay Motor Co., 29I Pa. 507, I40 Atl. 506 (I928).

35 Erwin Billiard Parlor v. Buckner, 156 Tenn. 278, 300 S.W. 565 (1927).

${ }^{36}$ Guaranty Trust Co. of New York v. Hannay \& Co., [1915] 2 K.B. 536 (C.A.).

${ }_{37}$ Ertel Bieber \& Co. v. Rio Tinto Co., [I9I8] A.C. 260 (H.L.).

${ }^{8}$ Russian Commercial \& Industrial Bank v. British Bank for Foreign Trade, [192I] 2 A.C. 438 (H.L.).

39 Ruislip-Northwood U. D. C. v. Lee, x45 L. T. R. 208 (K.B., I93 I). 
be construed at the initiative of any party in interest, now universally admitted, why not other instruments, such as contracts, deeds, leases, statutes, policies, patents, etc.? It required the declaratory action to recognize the value of construing these instruments, because equity, aside from the customary equitable remedies, seemed unwilling to extend its functions beyond the construction of wills or to permit a trustee or receiver to seek advice or directions.

The necessity of proving that the plaintiff's petition or bill came under an established head of equity jurisdiction limited the early vaunted flexibility of equity and cast it into the mould of a crystallized system. No similar development has occurred in the evolution of the declaratory action, which is not a system but remains a vehicle of relief only. While equity is applied to a number of given situations alone and its remedies are well established, the declaratory action has been applied to every type of issue that can arise. The only limit is that the court must declare the pre-existing rights of the parties, not establish a new status. Again, where there is a special statutory, usually administrative, remedy for the particular kind of issue in hand, e.g., income taxation, the declaration is excluded. But so would be all other remedies. Also, when an identical case is already pending between the same parties, it is usual to refuse declaratory relief.

Equity operates for the most part coercively, only a few of its remedies, like injunction, and bills quia timet, including the removal of clouds on title to realty and quieting title, operating in part preventively. The declaratory action settles the disputed rights of the parties, but operates primarily but not necessarily preventively only. The equitable remedy, such as the injunction, usually requires a bond proportionate to the interest of which the defendant is deprived; a declaration does not. ${ }^{4}$ Whereas most equitable, like legal, remedies condition their relief as a curative agency on prior violation, breach, the sundering of established relations and irretrievable hostility, the declaratory action requires only evidence of a dispute as to jural relations. It requires no violation, no breach, no sundering of established relations and therefore no irretrievable hostility. It is therefore a much more civilized method of adjudication.

Whereas in equity, as in law, only an aggrieved plaintiff can sue, whenever he gets ready, the declaratory action assumes that a prospective obligor or defendant may either be aggrieved by a false claim or burdened by a new event or obsolescence and therefore permits him to initiate the action for relief. As Mr. Chief Justice Hughes remarked:

${ }^{40} \mathrm{Z} \&$ F Assets Realization Corp. v. Hull, 3 II U.S. 470 (I94I). 
But the character of the controversy and of the issue to be determined is essentially the same whether it is presented by the insured or by the insurer. ${ }^{45}$

If the party charged denies and challenges the validity of the assertion, he may force the "slanderer" to prove it in court or ever thereafter remain silent-one of the oldest forms of Germanic judicial relief. ${ }^{42}$ The declaratory action preserves by statute the constitutional right to a jury trial; equity does not.43 History has long been familiar with many types of cases in which the judgment was nothing but declaratory. 44

When it is said that the main occasions for the declaratory settlement of disputed issues lie in the field of (I) personal status, (2) the validity and construction of all types of written instruments, including contracts, deeds, leases, mortgages, liens, corporation and partnership documents, insurance policies, statutes, patents, and wills, (3) facts, future interests, trusts, estates, titles to property, real and personal, and (4) administrative duties and powers, elections, public officers, and taxation-there is little left in the field of litigation.

Equity requires of the plaintiff a recognizable title to legal protection, as established by the precedents. The declaratory procedure requires only that he demonstrate an economic or social interest, which it is very sensitive to protect and thereby denominate as "legal." 45 Thus it is continually expanding the conception of "cause of action," which equity by reason of its limitations is tending to narrow. Equity requires a defendant to take a position actually adverse to the plaintiff; the declaratory action requires only the vindication of the actor's claim of right against a potentially adverse party. Equity requires proof that there is no adequate remedy at law, though there is much litigation about what is "adequate"; the declaratory action requires no such proof ${ }^{6}$-not even that there is no adequate

${ }^{41}$ Aetna Life Ins. Co. v. Haworth, 300 U.S. 227, 244 (I937).

$4^{2}$ Borchard, Declaratory Judgments 99 et seq. (2d ed. I94I).

43 That declaratory relief seeking equity did not enlarge the provision for jury trial, see Linahan v. Linahan, I3I Conn. 307, 39 A. 2d 895 (I944).

${ }_{44}$ See the cases mentioned in Borchard, op. cit. supra, note 42 , at 137 , et seq.

${ }_{45}$ The conception of "person aggrieved," has been widened by statute so as to confer a right of intervention or right of action on consumers and outsiders who, while not made parties of record, are vitally concerned in the outcome of a litigation. Associated Industries of New York State v. Ickes, I34 F. 2d 694, 702 (C.C.A. 2d, I943); Federal Communications Com'n v. Sanders Brothers Radio Station, 309 U.S. 470, 642 (1940); Scripps-Howard Radio, Inc. v. Federal Communications Com'n, 3 I6 U.S. 4 (I942); Stark v. Wickard, 321 U.S. 288, 308 (1944); United States v. Public Utilities Com'n of the District of Columbia, decided Septemper 24, 1945, by the Court of Appeals for the District of Columbia.

${ }^{6}$ In holding that an exclusive licensee need not be joined as a defendant with infringer in a suit for a declaratory judgment, as he would have to be in a suit for infringement of patent, Judge Nields remarked in Bakelite Corp. v. Lubri-Zol Development Co., 34 F. Supp. I42, I43 
remedy in equity, since it is a remedy alternative to others and not exclusive-in spite of the fact that the Indiana and Maryland, 47 and, formerly, the Pennsylvania courts have thus misconstrued it and thereby all but deprived their citizens of a valuable remedy authorized by statute.

Equity requires all the conditions of equitable relief of the character sought; the declaratory action makes no such conditions. An equitable action must take its place on the calendar; the declaratory action in many jurisdictions by reason of its conciseness, speed, inexpensiveness, and its tranquillizing function, can be moved to the head of the calendar. Equity acts primarily in personam; the declaratory action operates as the is-. sue may require. The judgment of a court of common law creates or establishes rights in the plaintiff, like the declaratory judgment, where judgment does not fall to the defendant; the decree of an equity court imposes enforceable duties on the losing defendant. The declaratory action may prescribe the jural relations of either, as sought. Equity is restricted in scope; the declaratory action may be brought in any case, legal or equitable, or neither. Equity, as a condition of obtaining the rescission of an obligation, requires a tender, early or late, of the consideration received by the movant; in seeking the declaration of the invalidity of an instrument or obligation, no tender of the consideration received is required. ${ }^{8}$

Equity looks to a certain type of coercive relief not grantable in law courts; the declaratory action looks only to an adjudication, which suffices to settle all issues raised. Equitable remedies cannot always be sought in combination with any other form of relief; but the phrase, "whether or not further relief is or could be claimed," in the statutes serves to indicate that the declaratory action can be brought $(x)$ in combination with any other form of relief, (2) alone, if so desired, and (3) even where no other form of relief is available. As the courts are unable to harden the declaration into a system, the declaratory action retains its original flexibility and expansibility, free from stultifying technicalities.

It is customary to say that the declaratory action has not increased the court's jurisdiction, since it is procedural only. In a sense this is correct, for the subject matter dealt with by courts remains the same. In other

(D.C. Del., I940): "A declaratory-judgment suit is not a suit in equity and differs from equity suits in important respects. Absence of an adequate remedy at law is requisite to a suit in equity. That rule is not applicable to suits for declaratory judgments." He then quoted Federal Rule 57 .

47 The Maryland statute has been amended, Md. Ann. Code (Flack Supp., r945) c. 724, so as to overrule the Court of Appeals and reiterate the legislative intent.

$4^{8}$ Salada Beach Public Utility Dist. v. Anderson, 50 Cal. App. 2d 306, I23 P. 2d 86 (I942). 
respects it is not true. The declaration has opened the shutters of the forensic camera much wider and admits to judicial cognizance an entirely new group of interests, including aggrieved persons who, being prospective defendants to ordinary actions, were not perceived theretofore by the law until they were sued. They were not allowed to initiate proceedings. As already observed, the disquietude and uncertainty of a prospective defendant and obligor, like an alleged infringer of patents, the covenantors of a building restriction, lessees equally with lessors, justify judicial relief. Even administrative tribunals have felt the need of such a procedure. And this has the added advantage of not breaking the legal bond between the parties while they litigate their respective conflict of views. This is a development which deserves the utmost attention, for it has turned a somewhat uncivilized hostile dispute into a civilized proceeding for the adjudication of differences bound to arise. It may involve mainly the construction of written instruments, which are of vast scope; but social conflicts, becoming legal, are by no means confined to that source.

This great field of adjudication was theretofore completely closed to any relief, and while all existing forms of action could be converted into the alternative form of a judgment seeking a declaration of rights, especially where it was desired not to break social or economic relations, and for that reason has aroused the fear of some judges that the declaration might thus replace existing forms of action, the fact is that experience indicates that perhaps 95 per cent of plaintiffs desire coercive relief in some form and therefore have no occasion to seek merely a declaratory judgment. But the practice of seeking injunction and other forms of coercive relief in order to obtain what is in essence a declaration ${ }^{49}$ might be materially tempered and corrected since the injunction, like other coercive remedies, is in many cases one of those fictions which help to satisfy a social need. The declaration actually sought can henceforth be openly requested.

Closely related to this branch of the subject is the effort of endangered professional or businessmen, the target of police power or other regulatory legislation, to challenge the validity or construction of the statute which restricts them. Here again our courts, with due respect to them, are somewhat callous to the interests involved and their impairment by a threatening statute. The courts invoke familiar doctrines that courts of equity do not ordinarily restrain criminal prosecutions, ${ }^{50}$ and that no "citizen or

49 Terrace v. Thompson, 263 U.S. I97 ( (923) $^{2}$; Pierce v. Society of Sisters, 268 U.S. 5 I0 (1925); Village of Euclid v. Ambler Realty Co., 272 U.S. 365 (I926).

${ }^{50}$ In re Sawyer, I24 U.S. 200, 21 (I888); Davis and Farnum Mfg. Co. v. Los Angeles, I89 U.S. 207 (Ig03); Hygrade Provision Co. v. Sherman, 266 U.S. 497, 500 (I925). 
member of the community is immune from prosecution, in good faith, for his alleged criminal acts." ${ }^{5 x}$ But it is not an adequate remedy to become a defendant in a criminal prosecution when it suits the district attorney to commence it, nor need a defendant await the pleasure of his creditor to commence a suit, as the common law assumed. Study of the declaratory action and its operation has disclosed that a charge of illegality impairs the prospective defendant's interests and that he has a right to ward off the impending danger. To characterize a businessman desiring to thread his way among the myriad of regulatory statutes as a criminal, because the statute carries a penalty, is a distortion of language. The law should facilitate, not hinder, his effort to challenge or construe the statute or ordinance which assails him. I have ventured to write an article defending the business or professional man's power to challenge civilly the validity or construction of such a statute, and some of the courts have seen its advantages to the state over the traditional criminal prosecution. ${ }^{52}$

As an incident of this civil procedure, attention may be called to the Connecticut statute forbidding a physician from giving birth-control advice, a statute challenged by civil declaratory action in Tileston $\mathrm{v}$. Ullman..$^{53}$ In that case the target of the statute, Dr. Tileston, a physician, citing in the record three women in need of the advice, as attested by other physicians, was denied standing in court on the ground that the three women should have been made parties of record and been joined as plaintiffs. But this seems incongruous, since he alone was the target of the statute. ${ }^{54}$ Only the giving, not the receiving, of advice was purported to be punished by the statute. If the prospective victim of the statutory prohibition cannot make himself the complainant in a civil action without danger of dismissal, the declaratory action has been deprived of much of its purpose.

This is not to contend that the courts should not exercise their usual

$5 x$ Beal v. Missouri Pacific Railroad Corp., 3 I2 U.S. 45, 49 (I94I).

52 Dill v. Hamilton, 137 Neb. 723, 29I N.W. 62 (1940); New York Foreign Trade Zone Operators, Inc. v. State Liquor Authority, 259 App. Div. 993 , 20 N.Y.S. 2 d 986 (I940), rev'd $28_{5}$ N.Y. 272,34 N.E. 2d 316 (I94I); Borchard, Challenging "Penal".Statutes by Declaratory Action, 52 Yale L. J. 445 ( $x_{943)}$. The federal Supreme Court has its own device not to pass on the constitutionality of any section of a statute until the lower court has construed it. Alabama State Federation of Labor, Local Union No. I03 v. McAdory, 65 S. Ct. I384, I389 (I945); Asbury Hospital v. Cass County, N.D., 66 S. Ct. 6I, 64 (I945); see also Coffman v. Breeze Corporations, 323 U.S. 3 I6, 324 (I945).

${ }^{53} 3$ I 8 U.S. 44 (1943). The writer was counsel in the case and may possibly be biased. He has tried to avoid bias.

${ }^{4}$ Carpenter, Current Constitutional Law Decisions of the United States Supreme Court, I6 So. Cal. L. Rev. 220, 224 (I943). 
caution incident to demanding a full hearing from both sides before issuing a declaration. The point is well illustrated in Witschner v. City of Atchison. ${ }^{55}$ There the owner of a pin-ball machine affording the successful winner a certain number of replays sued the chief of police and the city for a declaration that the machines he intended to introduce into the city were not gambling devices. The chief of police'evidently wanted the assurance of a decision to that effect, for he put in only a perfunctory, and not a serious, defense. Thereupon, the court properly declined to render a decision in the case, holding that such an issue should be contested and warranted a decision only after the facts were thoroughly debated by both sides. This was a correct decision because the court should not have been asked to place the stamp of its approval on such ambiguous machines without having all the evidence it considered necessary; besides which, no machines had yet been introduced into the city, possibly a sufficient ground for dismissal alone. The court added, more questionably, that the declaration operated like an injunction and that equity does not enjoin a criminal prosecution..$^{6}$

\section{III}

\section{LIMITATIONS INHERENT IN EQUTTY}

Whether we say that equity has only limited jurisdiction or else that it has complete jurisdiction but that courts have limited its exercise, the result is the same. Equitable rights and remedies are associated with certain limitations which courts pretty strictly enforce.

It is common, in dealing with the topics brought by equity under its control, to divide the field into (I) equitable titles; (2) equitable rights; and (3) equitable remedies..$^{57}$ Under the first head Bispham, for example, includes all aspects of trusts, express or implied, mortgages, and assignments. Under the head of equitable rights he discusses the effects of accident and mistake, fraud (actual and constructive), notice, equitable estoppel, and election, conversion and reconversion, adjustment (includ-

${ }^{55}{ }_{54}$ Kan. 212 , II7 P. 2 d $57^{\circ}$ (I94I).

${ }^{6}$ The state ought to be content with a civil adjudication, where its burden is limited to proving its case by a preponderance of evidence, instead of "beyond a reasonable doubt." A court should not hesitate to grant the former, because it would not prevent the bringing of the latter, where the state's burden would be greater. Very unusual is the recent action of a Wisconsin Attorney General, who, after an acquittal was obtained by a dairy concern in a prosecution for the sale of milk in bottles other than authorized by a statute, brought a second action against the concern for a declaratory judgment. State ex rel. State Department of Agriculture v. Land O'Lakes Ice Cream Co., 247 Wis. 2626, I8 N.W. 2d 325 (I945).

57 Bispham, The Principles of Equity (McCoy's ed. I93r). 
ing contribution), set-off, exoneration, subrogation and marshaling, and liens and other pledges. Under the head of equitable remedies he discusses specific performance, the various types of injunctions, reformation, rescission and cancellation of contracts, accounting, partition, dower and boundaries, partnership bills, creditors' bills and administration suits, the protection of infants, idiots, and lunatics, discovery, bills quia timet, receivers, the writ of ne exeat, the bill to remove cloud from title, the bill to quiet title, etc.

In one section ${ }^{58}$ Bispham expressly states that "courts of equity will not entertain bills solely to declare rights." This, as already observed, was an exceedingly dubious pronouncement, but it helps to explain why equity receives a technical construction, and hence necessitates the modern expansion of the declaratory action as an independent branch of the law, neither legal nor equitable but partaking of the character of both and meeting situations of dispute, doubt, fear, peril, and insecurity which equity proved unable to meet. Some of the differences in result between the rigidity of equity and the flexibility of the declaratory action will be illustrated by the following discussion, which, owing to considerations of space, will deal with only a few of the equitable remedies.

Injunctions. We have already mentioned the fact that injunctions have often been sought and allowed, and abused, in order to obtain a declaration of rights. Sometimes, however, in such cases the injunction may be refused for procedural or substantive reasons, and hence no decision is made. This was the cass in Hurley $\mathrm{v}$. Kincaid, ${ }^{59}$ which involved an injunction to prevent Army engineers from flooding the plaintiff's land. The case was before the courts five times on the propriety of the injunction, when all the plaintiff really sought was light on the issue of "taking" under the Tucker Act.

In the case of statutes carrying a penalty, the court, by refusing injunction, thus places the petitioner in the position of violating the statute or abandoning his rights, when his only purpose is to find out what the statute means. This is true in cases like Shredded Wheat Co. v. City of Elgin, ${ }^{60}$ where an ordinance required a local license as a condition of sales. The court declined to issue the injunction requested on the ground that this would be the enjoining of a criminal statute. The plaintiff was free, it said, to incur the penalty, and the court would then decide either that it was an invalid statute, in which event the petitioner was free, or that it was a

${ }^{8}$ Tbid., $\$ 539$.

59285 U.S. 95 ( 1932$)$.

${ }^{60} 284$ Ill. 389 , I20 N.E. 248 (I9I8). 
valid statute, in which event he ought to incur the fine. It took some years to perceive that a petitioner should not be placed in the dangerous and invidious position of having to eat the suspect in order to find out whether it was a mushroom or a toadstool; that on proof of his interest he should be allowed to challenge the statute before, not after he incurs the penalties fixed. ${ }^{6 x}$ Not only is speed thereby achieved, but the awkwardness of incurring penalties as a condition of adjudication is avoided.

We have ventured in a separate article ${ }^{62}$ to question the administrative propriety of refusing to enjoin a statute or ordinance which prescribes regulations for the business or professional man on the ground that the legislation carries a penalty; instead, we have shown the advantages inherent in a declaratory judgment.

It is established that the conditions of a bill of injunction are not necessary to a suit for a declaratory judgment. Mr. Justice Stone remarked in Nashville, Chattanooga \& St. Louis Railway v. Wallace:

As the prayer for relief by injunction is not a necessary prerequisite to the exercise of judicial power, allegations of threatened irreparable injury which are material only if an injunction is asked, may likewise be dispensed with if, in other respects, the controversy presented is, as in this case, real and substantial..$^{63}$

It is submitted that the threat to enforce a statute, sometimes apparently believed necessary to a challenge of its validity, ${ }^{64}$ should play no part in a declaratory action. It has been disregarded in such injunction suits as Pierce v. Society of Sisters ${ }^{65}$ and Village of Euclid v. Ambler Realty

6x Terrace v. Thompson, 263 U.S. 197,216 ( 1923 ), an injunction granted, Justice Brandeis dissenting, in which Butler, J. held: "They are not obliged to take the risk of prosecution, fines and imprisonment and loss of property in order to secure an adjudication of their rights."

To show the beneficent effects of a declaration of legality before purported violation, see Erwin Billiard Parlor v. Buckner, 156 Tenn. 278, 300 S.W. 565 (I927) (injunction denied but declaration issued); Barron v. City of Minneapolis, 212 Minn. 566, 4 N.W. $2 \mathrm{~d} 622$ (1942); Dill v. Hamilton, $x_{37}$ Neb. 723, 29 I N.W. 62 (I940); State ex rel. Ward v. Republic County Commissioners, $148 \mathrm{Kan} .376,82 \mathrm{P} .2 \mathrm{~d} 84$ ( 1938 ), in which was involved the legality of the expenditure of public funds to erect public buildings in a Kansas county. The court said, at 384-85: "This case is a good illustration of the beneficial use of our act relating to declaratory judgments .... when counsel and the courts cooperate for the early consideration and determination of a question of public importance concerning which there is an actual controversy. This action, framed for an injunction but actually seeking a construction of statutes and a declaration of rights, was filed and heard in the district court, appealed to this court, advanced, argued and decided, all within a week. Counsel acted prudently in bringing the action in order that the validity of the proceeding being taken by defendant might be determined at an early date."

\footnotetext{
62 Borchard, op. cit. supra, note 52.

63288 U.S. 249, 264 (I933).

64 Cf. Ex parte La Prade, 249 U.S. 244 (I933), and 5 I Harv. L. Rev. I270 (I928).

${ }^{6} 268$ U.S. $5^{10}\left(\mathrm{Ig}^{25}\right)$.
} 
Co ${ }^{66}$ The impairment of the plaintiff's interests is accomplished by the statute itself, which hangs suspended over his head, not by the threat of the attorney general. By silence, agreeing not to enforce, or concurrence with the plaintiff, the attorney general thus has it in his power to prevent adjudication. Nor should it be necessary for a successor to renew the original threat as a condition of adjudication. ${ }^{67}$

Since the main purpose of an injunction is often to obtain a declaration of the substantive rights of the parties, it follows that where an injunction would lie, a fortiori a milder declaration may be sought and granted. ${ }^{68}$ Where an injunction is granted the grounds may be sufficiently clear and the legal relations sufficiently explained so as to make an additional declaration unnecessary. But as we shall explain in a moment, the declaration is often granted in addition to the injunction in order to clarify the position for the future and is granted instead of the injunction because the facts are not deemed to warrant so drastic a remedy.

The importance of seeking a declaration and an injunction in the alternative is that the abuse of the injunction may become unnecessary and the declaration alone suffice. Indeed, the court may sua sponte grant a declaration where an injunction alone is sought. ${ }^{69}$ At all events, a decision is rendered on the merits, whether an ancillary injunction is granted or not. The injunction may indeed follow the declaration, should the declaration not be observed. ${ }^{\circ}$

Specific Performance. Equity has erected around the decree of specific performance a number of limitations which aid predictability but materially limit its application. In the matter of enforcing contracts, the supposed discretion of the judge is limited by the adequacy of the remedy at law and by its practicality. In addition, the judge must satisfy himself that the contract has been concluded, that it is certain, unambiguous, mutual, and upon a valuable consideration, that it is fair in all its parts, free from any misrepresentation or misapprehension, fraud or mistake, imposition or surprise, that it is not an unconscionable or hard bargain, that its performance is not oppressive upon the defendant, and finally, that it is capable of specific execution through the decree of a court.

${ }^{66} 272$ U.S. 365 (Ig26).

${ }^{67}$ Ex parte La Prade, 249 U.S. 244 (1933); Federal Rules of Civil Procedure, Rule 25(d).

${ }^{68}$ Childs v. Marion County, I6 3 Ore. 4II, 97 P. 2d 955 (I940).

${ }_{69}$ Hasselbring v. Koepke, 263 Mich. 466, 248 N.W. 869 (r933).

${ }^{70}$ Borchard, op. cit. supra, note 42 , at $435-36$; see also the combination of the declaration with other forms of equitable relief, ibid., at $436-37$. 
While it is often believed that the line of distinction lies between real and personal property in that a contract for the purchase of real property will be specifically enforced but not a contract for personalty, actually the distinction lies in the fact that damages at law will not furnish an adequate remedy in the case of land.contracts, but that they will suffice in the case of personalty. Formerly, when the vendee refused to take conveyance on the basis of an unmarketable title, the vendor's only remedy if an outside interest interfered was to buy in the alleged interest objected to and in the suit for specific.performance allege and prove that his legal title was complete, and that there was no ground to fear that the same facts could not be proved thereafter, facts which would protect any purchaser. Specific performance was not usually decreed where there was a probability of adverse claims emanating from a third party subjecting the purchaser to litigation, since the decree bound only vendor and purchaser, and not third parties. ${ }^{7 I}$

It will at once be recognized that while the remedy of specific performance is highly precarious and dependent upon a large mass of conditions all of which must be satisfied, it is nevertheless coercive upon the defendant. Coercion has little advantage over an enforceable declaration of rights, and some disadvantages in human relations. The supposed discretion of the judge is controlled by the conditions of specific performance to a point where it becomes exceedingly limited. Far more useful in most cases is the declaration of a court that the defendant is under a duty, invokable either by the plaintiff or the defendant. No conditions are essential to the establishment of this legal fact. If the defendant is responsible, the decree is as useful as a decree of specific performance without the limitations attaching in equity. There is no place for the inadequacy of the legal remedy, no place usually for the doctrine that third parties are not bound.

The special value of the declaration, as already observed, lies in the fact that the contract need not be broken or purport to be broken as a condition of adjudication. In the face of an actual or anticipated breach by the defendant the declaration of the defendant's continuing liability serves usually a more effective purpose than does a suit for damages or injunction to prevent breach of contract, which is still an exceptional remedy reserved for special cases. In many cases, indeed, involving personal services with a covenant not to serve another, no mandatory injunction or

${ }^{7} 2$ Story, Commentaries on Equity Jurisprudence $\$ 986$ et seq. (Lyon's ed. Igr8); 4 Pomeroy, Equity Jurisprudence $\S$ I 400 et seq. (Symons' ed. I94I); McClintock, Handbook of Equity \& 5 r et seq. (1936). 
decree for specific performance can be granted, yet a declaration of the defendant's duty accomplishes most of the plaintiff's purposes. ${ }^{72}$

Apart from the other advantages of a declaration, any of the conditions attaching to a decree of specific performance may be individually placed in issue. A declaration may thus place a doubtful defendant on notice of the consequences of his proposed breach. The declaration thus serves as a stabilizer of the relation and enables grievances to be adjudicated prior to the breach. It thus enables duties to be declared prior to ascertainment of their extent, as in the case of indemnity contracts, where the insurer threatens repudiation on the ground of the plaintiff's breach. By enabling specific duties to be declared it serves the same purpose as a judgment for "specific performance, except that it lacks coercion, and operates in cases where equity fails. There are no limits to the substantive reach of the declaration of the defendant's duty and it thus performs a continuously pacifying, stabilizing function to prevent an impending breach. Needless to say, a plaintiff may also seek a declaration of his own duty. ${ }^{73}$

The construction of the contract is much preferable to a suit for damages which presupposes the end of the contract. Disputes as to whether a plaintiff has broken the contract and thus released the defendant from his obligation are readily determined by declaration, while the contract is alive. Of great value is action before one or the other party purports to break the contract-an action especially useful in suits between seller and buyer, and lessor and lessee, as to who must bear or share losses due to act of God. Declarations have been issued deciding the defendant's disputed duty to take materials over a period of time, to supply the plaintiff with water or power, to furnish services or materials, to set aside funds, to pay an employee's salary or income taxes, to pay interest in gold and not in paper, to accept payment in stock as agreed, to remove tracks, to transfer stock, to exercise a buyer's option, to pay an annuity, and to perform other duties.

It is common to challenge the marketability of the plaintiff's title by suing out a vendor's and purchaser's summons leading to a declaration of title. The declaration of the defendant's duty may turn upon the construction of all forms of written instruments from deeds to patents, issues all of which may be raised before irretrievable acts of injury have been under-

${ }^{72}$ Columbia Pictures Corp. v. De Toth, I6r P. 2d 2x7 (Cal., I945) (contract oral and for personal services).

${ }^{73}$ This is the common recourse of trustees and other fiduciaries, who thus seek to obtain the protection of a judgment before acting. See also many cases cited in Borchard, op. cit. supra, note 42 , at 535 et seq. 
taken. We shall refer hereafter to the valuable privilege of the covenantor to raise the issue of the obsolescence of his covenant before breach. Sellers or buyers may sue for a construction of the contract or, in the event of past breach, may sue for a declaration of right to damages and specific performance. The opportunity thus to combine legal with equitable relief is in some states inestimable.

Declaratory relief is applicable not only to disputed titles to property but to all interests in property, real and personal. The technicalities of ejectment and removing clouds in equity are unnecessary in the face of so peaceful and conclusive a method of adjudication. Both the technical real action and the mixed action of ejectment with its several fictions become now unnecessary. In challenging the powers of the administration, suits. for specific performance or injunction are not readily granted, but a simple declaratory adjudication of the illegality of the act serves as an effective remedy.

Bills To Remove Cloud on Title. The bill to remove a cloud from title and the bill to quiet title are both illustrations of the bill quia timet, designed to allay a fear of impending or possible future impairment of a title to real estate. In turn, the extended bill quia timet has historically had a slightly different function from the other two, though embracing them. Modern statute has changed these early remedies in most jurisdictions and made them in the main methods of trying title. Personal property may also be protected by statute against adverse claims. Yet their historical differences prevail in a few jurisdictions and may justify brief comment. The bill to remove a cloud on title was originally a technical bill available only to a plaintiff who possesses legal title and who as a rule is actually in possession; and the cloud to be removed must be (a) not void on its face; (b) in the form of an instrument or proceeding of record, and not a mere verbal claim; and (c) so clearly prejudicial to his title that the value of his estate is impaired. The second document had to be ostensibly valid, therefore vexatious, and not obviously void.

Some of these requirements have been ameliorated by statute, but the bill is still essentially technical. There must be an injury to the jus disponendi for which the law affords no adequate relief. There are usually three requisites which must be met by the plaintiff: (I) he must have a substantial interest in the property; (2) there must be an absence of a legal remedy; (3) the adverse claim attacked must constitute a serious cloud upon the marketability of title in the eyes of a reasonable purchaser. The mere fact that investigation may prove the claim to be void 
is not enough to dissipate fear. ${ }^{74}$ Howard shows ${ }^{75}$ that apart from statute only a few jurisdictions have developed bills for the removal of cloud from title as a logical and independent ground of equity jurisdiction, unhampered by the limitations attached to bills for cancellation. Clouds may also be removed as an incident of other equitable relief.

In its narrow sense, the "removal of clouds" is used in equity to indicate bills seeking relief against possible loss of evidence in a threatened litigation. It was occasionally used to prevent a transfer of negotiable instruments from an estopped payee into the hands of a bona fide holder for value. In a few states one out of possession may now bring the action. Since the statutory legal action to try title or the marketability of title prevails in most states, there is less occasion to resort to equity.

As in most bills quia timet, the cloud is removed (a) by enjoining the defendant from asserting his claim; (b) by cancelling the instrument upon which he relies; (c) by requiring him to convey or release his claim, a decree which presupposes an action in personam; and (d) by declaring the defendant's claim void, a proceeding for a declaration or grantable in equity when jurisdiction in rem is obtained. ${ }^{76}$

In bills quia timet the injury is assumed in the fact that, after title has been sustained in ejectment, successive suits may create future injury, so that there is a present interest in preventing the anticipated mischief and preventing future litigation. The purpose of quia timet relief is to preserve the means by which existing rights may be protected from future or continued challenge.

The original bill to quiet title independent of statute was invokable by the one in possession having full legal title, ${ }^{77}$ after successive legal actions,

74 Howard, Bills To Remove Cloud from Title, 25 W. Va. L. Q. 4, Iog, at II (I9I7-I8).

75 Ibid., at $\dot{\text { Ir } 3 . ~}$

${ }^{76}$ Ibid., at $x 25$.

7 An equitable interest is not enough. Clark, Principles of Equity $\S 4$ I5 (I937). Justice Brandeis for the Court in Twist v. Prairie Oil \& Gas Co., 274 U.S. 684, 69I (I926), stated: "It is true that ordinarily one out of possession may not bring in a federal court a bill to quiet title against one in possession, because there is a full, adequate and complete remedy at law and the defendant is entitled to a jury trial." He pointed out that special facts, a particular form of relief or waiver of the objection of lack of jurisdiction might create an exception to the rule. If the plaintiff is out of possession and cannot for some reason sue in ejectment, cancellation is the proper remedy. Clark, op. cit. supra, $\$ 4 \mathrm{I}_{5}$ et seq.; McClintock, op. cit. supra, note 7I, at 333-36; Equity Jurisdiction To Remove Clouds on Title Acquired by Adverse Possession, 9o U. of Pa. L. Rev. 475 ( $\mathrm{r}_{942}$ ). Generally, when neither party is in possession a bill in equity may be maintained. As to the strictness of equity in demanding compliance with its conditions, see United States v. Wilson, Ir8 U.S. 86 (r886), and Whitehead v. Shattuck, I38 U.S. I46 (r89r); Willing v. Chicago Auditorium Ass'n, 277 U.S. 274 (I928); MissouriKansas-Texas Railroad Co. v. Sanders, 45 F. Supp. 602 (W.D. Okla., r942). On the other 
all of which had failed, had been instituted against him by a person out of possession or where several persons asserted equitable titles against the legal or equitable owner. He had thus successfully sustained his title at law, but it assumed an inability to obtain further protection at law. The bill to quiet title was originally in the nature of a bill of peace to prevent numerous ejectment actions. ${ }^{78}$ The original jurisdiction has been greatly enlarged by statute to include all suits in equity by a claimant to establish his title to lands, including the removal of clouds.

It will be apparent that all these equitable actions to clear a title to real property are technical in character and involve conditions which only few can meet. They resemble most closely the declaratory action, which is designed not only to clear titles to realty but rights of all kinds and character, including status, a title of any kind to realty and personalty, and the privilege of acting or not acting. Every right, privilege, power, and immunity may be declared against an adversary, actual or potential, whether it arises out of a written instrument or otherwise, provided only that the issue be presented in justiciable form. Any claim, assertion, challenge, record or adverse interest which, by casting doubt, insecurity, or uncertainty upon the plaintiff's rights or status, damages his pecuniary or material interests, establishes a condition of justiciability. ${ }^{79}$ Whereas the bill to remove cloud from title requires a second instrument of record, and was the basis for the denial of relief in Willing v. Chicago Auditorium Association, the declaratory judgment finds one of its principal functions in clarifying the ambiguity found within the four corners of a single instrument-and this prior to purported breach. If the ambiguity warrants dissipation, a judicial declaration is obtainable either by private persons in interest or by public authority. ${ }^{80}$

The plaintiff's dilemma may arise not only out of ambiguity of the

hand, for the ease with which a declaration is obtained, see Reid v. Reid, $230 \mathrm{Ky} .835,20$ S.W. $2 d$ Ior5 (I929), wherein there was a declaration of a wife's rights in a home and lot under a deed conveying to husband and wife during their joint lives as tenants in common with remainder in fee to the survivor. The action was brought after the husband's death and was sustained against the objection that possession had not been alleged. The court pointed out that this was not a suit to quiet title but one for a declaration of rights.

${ }^{8}$ These bills and their limitations are discussed in Bispham, op. cit. supra, note $56, \S 543$; McClintock, op. cit. supra, note 7 I, $\$ \delta x 84-92 ;$ Eaton, Handbook of Equity Jurisprudence $\S \S 32$ I-22 (2d ed. I923); 2 Story, op. cit. supra, note 7I, § II4I et seq.

79 Borchard, op. cit. supra, note 42 , at 39.

8o Thus, the power of the President to seize Montgomery Ward \& Company under the First War Powers Act was raised by the government by declaratory action against Montgomery Ward. United States v. Montgomery Ward \& Co., 58 F. Supp. 408 (N.D. Ill., I945), rev'd I5o F. $2 d 3^{69}$ (C.C.A. 7 th, I945). 
instrument but by reason of a new event or occurrence which throws doubt upon the continuity of the relation. Thus, for the first time in judicial history the alleged infringer of a patent may initiate an action, provided the patentee has even faintly claimed infringement, to determine the validity of the patent, or that, if valid, he is not infringing. So, the covenantor of a restrictive covenant may, without first acting on his opinion, claim against the covenantee that the covenant has become obsolescent and that he is privileged to disregard it without penalty. Before the declaration was known, equity aided only the covenantee in enjoining violations of the deed or lease by the covenantor, unless the covenant in fact had become obsolete. But for the covenantor to act on his own conviction and risk forfeiture and damages was a risky method of obtaining adjudication.

Interpleader and Bills of Peace. Closely related to the equitable bills to quiet title are bills of interpleader and bills of peace, both designed to protect the petitioner against a multiplicity of suits. Perhaps its common law origin is the reason for the narrow construction of the conditions associated with bills of interpleader. The petitioner must prove that he is a disinterested stakeholder in possession, that the claims against him are for the same thing, debt, or duty, that they are derived one from the other or from a common source, and that he has created no independent liability by contract or otherwise. While some of these restrictions were lifted by the suit in the nature of a bill of interpleader, enabling equitable relief to be accorded where there was an operative fact other than double liability or vexatious suits, it still remains a technical action. The plaintiff under the new relief might now claim some personal interest in the event or subject matter. The defendant's claims might vary or the plaintiff might admit only a partial liability. The petitioner in addition had to turn the subject matter of the claim over to the court and file an affidavit disclaiming collusion with any claimant.

The bill of peace was designed to prevent useless litigation by settling in one equity suit a question which would be common to many actions at law or in equity, either repeated actions as between one plaintiff and one defendant, or numerous actions between one plaintiff and several defendants.

Even the Federal Interpleader Act of $1936{ }^{8 \mathrm{x}}$ adopted primarily for the benefit of insurance companies against whom multiple claims are instituted, and Federal Rule 22, still expose the petitioner to the scrutiny of a court seeking compliance with the conditions of interpleader. If present,

${ }^{8 x}$, Chafee, The Federal Interpleader Act of 1936, 45 Yale L. J. 963, Ir6I (1936). 
they terminate in a declaratory judgment that the petitioner owes the debt to one specific person rather than to another.

The declaratory action covers a far wider range of fact situations. Instead of the bill of interpleader, a debtor, receiver, or stakeholder admittedly owing money, but not certain how much or to whom to pay or distribute the funds in his hands, may seek against conflicting claimants to determine the proper payee or distributee. He thereby obtains protection against all the claimants and protects the payee against the claims of other creditors, all of whom should be cited. The action may determine the particular rank, preference, or priority of a given class of designated claimants. ${ }^{82}$ It enables every conceivable form of debtor to bring a declaratory action against his creditors in the alternative, regardless of any conditions associated with equity. ${ }^{83}$ In particular, he need not deposit the amount admittedly due in court, though without deposit he probably cannot compel the claimants to sue each other. He may also enjoin other proceedings. The only advantage that the federal Interpleader Act has over the declaration is that process in the former case runs throughout the United States, whereas in the latter, as in other ordinary actions, it runs only within the state.

Rescission and Cancellation. This equitable remedy is also hedged about with procedural and substantive requirements. The contract will be rescinded and canceled only for mistake, fraud, or illegality. The mistake must occur in its inception, it must be mutual and relate to the essence. If unilateral, the other party must have unfairly, as in fraud, taken advantage of it. ${ }^{84}$ The plaintiff must show, apart from the usual equitable conditions, that irreparable injury is threatened. ${ }^{85} \mathrm{He}$ has an adequate remedy

${ }^{82}$ Orndoff v. Consumers' Fuel Co., 308 Pa. I65, 162 Atl. 43I (1923); Long Acre Press v. Odhams Press, [r930] $2 \mathrm{Ch}$. I96. As to the technicalities of interpleader, cf. 4 Pomeroy, op. cit. supra, note $7 x, \$ \delta 1320-29$, with Adair Lumber Co. v. Atchison, Topeka \& Santa Fe Railway Co., Ig F. Supp. 4I5 (W.D. Mo., 1937); see also Olsson, Bills of Interpleader, I4 Neb. I. Bul. I67 (I935).

${ }^{83}$ Cf. Russell v. Levi, 286 Ky. 5I, I49 S.W. 2 d 734 (I94I). It should be perfectly possible to sue several defendants to establish the extent to which each is liable for the plaintiff's injury; see for example, A. E. Joy Co. v. New Amsterdam Casualty Co., 98 Conn. 794, I 20 Atl. 684 (r923); see Borchard, op. cit. supra, note 42, at 260, for a criticism of the alleged misjoinder of defendants in the cases of Town of Manchester v. Town of Townshend, Iog Vt. 65, I92 Atl. 22 (1937); Porcelain Enamel \& Mfg. Co. v. Jeffrey Mfg. Co., I77 Md. 677, I I A. 2d 45 I (1940); and Schriber Sheet Metal \& Roofers, Inc. v. Shook, 64 Ohio App. 276, 28 N.E. 2d 699 (1940). It is common to sue two or more insurance companies jointly or in the alternative, Borchard, op. cit. supra, note 42, at 668.

${ }^{84}$ J. N. Pomeroy, Jr., A Treatise on Equitable Remedies; Supplementary to Pomeroy's Equity Jurisprudence $\$ \delta 2$ IO5-6 (2d ed. IgIg).

8s Ibid., at \& 2I07; Great Northern Life Ins. Co. v. Vince, II8 F. 2d 232 (C.C.A. 6th, I94I). 
at law even if his rights must remain inchoate and his tender of performance kept good until he is sued. ${ }^{86}$ There can be no rescission of a contract void on its face or where there is failure of consideration, unless so specified. ${ }^{87}$ Exceptional showing of probable dissipation of evidence, uncontestability after a certain period or a negotiation to holders in due course might induce rescission and cancellation. ${ }^{88}$ Some courts require tender of the return of consideration. ${ }^{89}$

All the effects of rescission plus the omission of technicalities, with the assurance of a jury trial on law issues can be obtained by a suit to declare the contract void. The action can, but need not, look to the avoidance of the whole contract; only part suffices..$^{90}$ As in all declarations, the adequacy of another remedy is immaterial. The proximity of apprehension of injury is not a condition of suit. Lack of substance in the claim is immaterial, if the plaintiff entertains an honest apprehension, or if there is only a potential claim. There is no need to tender back consideration. The defendant may by his counterclaim demand restitution. While the pendency of another suit may bar equity, it bars a declaration only when it is identical and coterminous. ${ }^{9 x}$

Indisposition to circumvent a jury trial is one reason for the restricted view of equity in allowing rescission and cancellation. In a declaration juries may be demanded by either party on questions of fact in traditional legal actions. ${ }^{22}$ Where a jury is feared rescission has advantages.

The equitable action shows a somewhat greater readiness of the courts to stay judicial proceedings in the state. In declaratory actions the federal courts show much hesitation in granting an injunction against state proceedings. ${ }^{93}$ This handicap is somewhat overcome by the ability to speed up the action for a declaration.

${ }^{86}$ Aetna Life Ins. Co. v. Richmond, 107 Conn. II7, I39 Atl. 702 (I927).

${ }^{87}$ Pomeroy, op. cit. supra, note $84, \$ \S 2$ ro7-9.

${ }^{88}$ American Life Ins. Co. v. Stewart, 300 U.S. 203 (I937); Mutual Ins. Co. v. Hurni Packing Co., 263 U.S. 167 (1923).

${ }^{89}$ Pomeroy, op. cit. supra, note 84 , § 21 ro. See supra, p. 158.

${ }^{\circ 0}$ Western Casualty \& Surety Co. v. Beverforden, 93 F. 2d I66 (C.C.A. 8th, I937).

${ }^{9 x}$ Aetna Casualty \& Surety Co. v. Quarles, 92 F. 2 d 32 I (C.C.A. 4th, I937).

${ }^{92}$ See, however, Pacific Indemnity Co. v. McDonald, ro7 F. 2 d 446 (C.C.A. gth, I939), 35 IIl. L. Rev. 339 (I940).

${ }^{93}$ Aetna Casualty \& Surety Co. v. Yeatts, 99 F. 2d $66_{5}$ (C.C.A. 4 th, r938) and 122 F. 2d 350 (C.C.A. 4th, I94 I) ; Maryland Casualty Co. v. Consumers Finance Service Co., ror F. $2 d{ }_{5}{ }_{4}$ (C.C.A. 3 d, 1938). 


\section{IV}

Aside from the cases in which the declaratory action may seek a declaration of the right to relief instead of the relief itself, a remedy fully adequate against a responsible defendant, there are two great types of cases which warrant attention and which equity only haltingly could remedy. These were (I) actions in which the plaintiff sought a declaration of his privilege to change the legal status quo without danger of penalty, forfeiture, or prejudice as threatened by the defendant, seeking thereby to avoid the risks of error or disaster; and (2) actions in which the plaintiff sought to maintain the status quo against an attempt of the defendant to change it to the plaintiff's disadvantage. ${ }^{94}$

\section{PERII}

In the former, which may be called avoiding peril, we have actions in which the plaintiff asserts his privilege and wishes by the declaration to avoid risks and avert dangers, emanating from the defendant in interest or another. He may place in issue his privileges under contract, claiming the privilege to act despite challenge or cloud. He may assert either his privilege of refusing to perform or the defendant's, rather than the plaintiff's liability for future losses. He may place in issue his own liability, his own privilege or his own immunity, all designed to avoid the necessity of breach. He may claim his special privilege under contract or the defendant's no-right to interfere.

He may seek to escape from contractual obligations by virtue of a new event, such as war or statute, placing in issue the effect of the new event on past privileges. He may seek a declaration of the effect of defendant's or the plaintiff's act on the plaintiff's obligation, or release from a contract because it is void or inequitable. In building and other contractual restrictions on the use of land he may seek by declaration a release from covenants that have become obsolete or inequitable before acting on his own conclusion. The declaration of release serves the valuable purpose of enabling new structures to be built, equipped with a green light instead of stopped by a red one. He may seek a declaration of the privilege of building specific structures. The covenantee may also claim by declaration the continued validity of the restriction. In lease relations this device has been particularly used to certify the privilege to sublet, or to declare a

94 All of the fact situations mentioned in this section have been the subject of judicial decisions, the citation of which is here omitted. In very few of them would equity have solved the plaintiff's dilemma. 
challenged lease valid or invalid, or to assure the privilege of renewing the lease at its expiration. Either lessee or lessor may claim specific privileges under the lease. A debtor may sue his creditor, disclaiming liability, limiting liability, or placing in issue the particular creditor when several claim a particular debt. The condition and privilege of discharging a debt or the form of discharge is frequently placed in issue.

Privileges which the plaintiff claims and the defendant denies are often derived not from contract or statute but from the common law. These are non-contractual in nature, designed to avert peril or penalty. Life tenants thus have frequently sued to establish their privileges of changing the status quo. Beneficiaries thus claim relief from forfeiture and may claim the existence of easements. With the growing interference of government with private business, the validity of government orders is frequently placed in issue before enforcement, and the timely challenge has the advantage of adjudicating legality without incurring penalties. The citizen may sue for his freedom from governmental requirements, ${ }^{95}$ his immunity from taxation and similar exactions. The government itself, as in the Montgomery Ward case, may place in issue its privileges under the law.

No longer need a public officer, like a sheriff, charged with duties to a private citizen by law, incur the risks of acting or not acting because he believes the law to be unconstitutional or misconstrued, and yet be disabled, by a peculiar quirk in our jurisprudence, from first challenging the constitutionality or construction of the law. Even the few states which protect the mistaken officer simply throw the risk on the unfortunate victim of the officer's mistaken act. The power of an administrative officer, whether challenged by him or by anyone else in interest, including the state itself or other public body, should be put to the test when first placed in issue and should not have to await his act, perhaps mistaken, as a condition of adjudication. The public power to borrow and spend may thus be promptly challenged and tested before and not after fatal action. No longer need an elected officer, whose eligibility has been challenged under a penal statute, have to occupy the office and run risks as a condition of testing his eligibility. The same method of declaration may be used by an officer, by the community, or by the administration when the term of an office or its prerogatives have been thrown into doubt and dispute. Nor need the officer be troubled by any of the technicalities of quo warranto, nor by the question whether he or the attorney general should start the suit.

95 Railroad Com'n v. Houston Natural Gas Corp., I86 S.W. 2d II7 (Tex. App., r945) (commission's power to act in certain ways challenged). 


\section{SECURITY}

We come now to the manifold situations in which the plaintiff needs and seeks a confirmation or recognition of his rights, as a safeguard against future impairment. This stabilization of legal relations is designed to afford security and, by relieving the uncertainty aroused by conflicting and adverse claims, to clarify the legal position, enable business relations to proceed without friction and with assurance, and preserve the social equilibrium. In times of rapid change and unlimited legislation, this need for security constantly arises and courts perform a useful function in appreciating this legal interest in security and protecting it by declaration. In these fact situations, the plaintiff does not wish to change his position, or escape a burden or imposition; on the contrary, he finds in the acts of the defendant or outside event a source of uncertainty or insecurity which warrants his demand for legal protection of the status quo, a confirmation of his rights, and an assurance of anticipated benefits.

The first of these needs for the security of acquisitions against impairment is the vindication of present rights, to prevent future injury or loss by failure of timely assertion, and more particularly by prescription, alleged waiver, negligence, or estoppel. One of the commonest needs of a person claiming a right is to prevent its loss or dissipation by the happening of future contingencies, including the lapse of time. It also becomes frequently necessary to safeguard an existing right, even though its exercise may have to be postponed until further facts have become established, or notwithstanding the fact that a condition precedent has not been literally fulfilled. There may often be sound reasons, moreover, to prefer at the moment a declaration over more drastic action-action which may indeed become unnecessary if it is possible to preserve a claimed right against impairment or loss by present assertion and judicial confirmation.

In all these cases a claimant having a right which is placed in jeopardy by force of circumstances or by the act of the defendant seeks a declaration which preserves or safeguards the right, without necessarily pursuing it to execution, in some cases because it cannot be then executed, in others because he prefers not to attempt to execute it but finds sufficient protection in a declaration of its existence.

Creditors, including mortgagees and unpaid vendors or suppliers of materials, in order to safeguard their rights against impairment often seek a declaration of the existence of a lien in their favor. So, a vendee may seek a declaration that, where the vendor failed to deliver, because of his bankruptcy, fire or other cause, the vendee has a lien for the money paid or on the insurance recovered by the vendor. 
An owner of property or a claimant of rights therein may sue for.a declaration that a defendant, who has already interfered with or is about to impair or interfere with his right by asserting an adverse claim, has noright to disturb the plaintiff's title, a decision which may depend upon the interpretation of a contract or statute.

The complicated nature of credit and security transactions necessarily brings in its train frequent contests among conflicting creditors seeking to establish the priority of their own claim or lien as against other claims of similar or different type. The contingency calling the conflict into life may be bankruptcy, death, the maturity of a debt, or some act or event placing the legal relationship of the parties in doubt, such as the attempt of one creditor to foreclose on his security, claim payment, enter judgment, or levy execution against the common debtor.

The advantage of these proceedings is that the issue of priority is segregated from the mass of issues likely to arise in receivership and that the administration of the estate can proceed smoothly. While it is true that the receiver himself can raise the issue of priority by a bill for instructions or an action for a declaration, he cannot be compelled to sue, a fact which should not bar creditors asserting preferences or priority from protecting their own interests against impairment.

A creditor is frequently faced with the necessity of establishing the existence of his claim against a debtor and, by asserting it, of preventing the improper disposition or the dissipation of assets normally chargeable with the payment of his claim.

Situations frequently arise in which a plaintiff seeks a declaration that property or rights, held in the name of another, actually belong to the plaintiff. The plaintiff finds his security in a judicial determination that the defendant holds as trustee for the plaintiff-a decision which affords him adequate protection.

By virtue of statute, contract, will, or other instrument affecting legal relations, a plaintiff frequently has occasion to assert his right to receive or retain benefits, without demanding more coercive relief. This may be due to the fact that he is not too certain of his legal right and wishes to avoid the risks of attachment or of a drastic change of the status quo, or, more likely, to the fact that the declaration of rights adequately protects his challenged interests. For the most part, such an issue involves the future conduct of the parties, which, by construction of the relevant instrument conferring the disputed right or title, is thereby stabilized and made certain. In the case of continuing relations it is especially valuable because it enables the doubt or uncertainty giving rise to the issue to be 
removed and settled without disturbing the relationship, thus avoiding that rupture, often irreparable, which other forms of procedure so often invite. And yet, notwithstanding these advantages of an action solely for a declaration, there is nothing to prevent a plaintiff from associating with his demand for a declaration of right to receive a benefit a further prayer for an order or decree to deliver or perform in accordance with the court's declaration. This declaration may take the form of a determination that a continuing obligation is still binding, that the original relation still remains valid and binding, of the identity of the recipient, or the form and amount of anticipated benefits.

No less important are those cases in which the relationship is alleged to have terminated and recourse is had to the courts so that the dissolution may be orderly, efficient, and observant of property rights. The dissolution of a marriage by divorce or separation may evoke circumstances whose practical solution lies in a declaration of the rights of the parties.

A plaintiff, in order to remain secure in his present position or to escape the dangers that an outside attack might invite, occasionally undertakes to protect himself by placing in issue the validity of his own past act. On the other hand, the contract may not yet have been entered upon, but may be imminent. The declaration may be sought because the defendant, or a third party, like the government, doubtful of the plaintiff's power to enter into the contract, refuses to give the plaintiff an advantage, e.g., advance money on loan, until the plaintiff's legal power to contract the loan has been established by declaratory judgment.

It frequently happens that new burdens are imposed by statute or by an unexpected event which affects parties to a contract but leaves them in doubt as to who is to bear, or in what proportion, the new burden. Instead of one refusing to bear it and compelling the other to sue at law for a specific sum in contribution, which would involve or risk a breach of the contract, it has been found expedient, without breach, for one of them to sue the other for a declaration of the plaintiff's privilege not to pay or of the defendant's duty to pay. This requires a construction of the contract in the light of the new and unanticipated event and enables them to proceed with assurance as to their respective rights. As a substitute for refusal and open breach it is a sensible method of litigating the disputed issue without disturbing the contractual status quo.

Those who have rights under contract or statute are frequently faced with a threat or risk of breach or violation by the defendant. Their fear of loss and prejudice persuades them to seek to avoid a breach by suing for a declaration of their rights. Such a declaration serves as a warning to the 
defendant and reassures the plaintiff in the enjoyment of his rights. It removes the cloud generated by the threat or danger of improper action by the defendant, confirms the plaintiff's rights, and stabilizes a doubtful or uncertain or challenged legal relation. It thus serves a most important social function in settling disputed rights at the inception of the controversy, saves from destruction and violence an existing status quo, preserves contracts against threatened breach, holds parties to their contractual and statutory duties, and avoids the economic and social damage which breach would entail. It acts as a preventive and conservatory measure, saving existing relationships from the risks of breach, violation, injury, and destruction. Issue is joined while the relationship still exists.

The status quo may be preserved against impairment by seeking to prevent the defendant from violating a contract or the law. The plaintiff thus asserts the defendant's no-right or disability to act to the plaintiff's injury. This type of security has usually been achieved by a bill of injunction, and while in these cases the prayer for a declaration is often combined with a request for injunction or other relief, an injunction is not always obtainable, whereas the declaration will usually serve as an adequate measure of preventive relief. The continuation of the act complained of is as a rule interrupted by a declaration of its illegality or invalidity, and that suffices.

This is the common form by which stockholders and members of organizations seek to prevent improper and ultra vires acts by their companies or societies infringing the corporate articles or by-laws and to preserve them against impairment, present and future.

In order to prevent long-continued violations of contract or law, it is often expedient to challenge the defendant's acts at their earliest manifestation by suing for a declaration of invalidity or illegality - that is, of defendant's no-right or disability to violate as planned or begun.

A plaintiff may establish his own security by seeking a determination of the defendant's powers, the exercise of which affects him. The need for such a declaration may lie in the plaintiff's desire to relieve himself from doubt and uncertainty and to clear his right, usually a right in property. The defendants may be public authorities or private persons, but the effect of the declaration is to remove a cloud from the plaintiff's rights.

$\mathrm{V}$

\section{Concluston}

This survey of certain types of cases in which the need for security in legal relations impels recourse to judicial relief will have indicated the 
unique function performed by the declaratory judgment. The settlement of disputed issues at their earliest manifestation, before loss and destruction have occurred consequent upon a hazardous gamble or guess as to one's rights, is thereby achieved. Adverse claims of the defendant calculated to injure the plaintiff or hamper his freedom of action and peace are determinable when first asserted and, if invalid, are removed, by mere declaration, as clouds upon the plaintiff's rights.

The unsettling effects of the existing crisis upon established legal relations, contractual and statutory, are likely to generate doubt, uncertainty, and dispute on every hand. An easy and inexpensive method of removing these disturbances and achieving security becomes indispensable. Whether the plaintiff asserts his right to escape an obligation or his right to hold the defendant to his duties, the action for a declaration of rights affords a speedy method of judicial relief from the uncertainty and insecurity attending times like these. Equity is too restricted to serve these purposes. War, fire, or other unanticipated disaster have been common causes unsettling legal relations in the past. Economic earthquakes, new legislation, or new inventions are as likely to cause changes of circumstance in the future. The very speed of modern life acting upon established relations requires judicial machinery to gauge and determine the effect of the resulting changes upon the status quo. In the declaratory judgment that machinery is made available, and social and individual peace and stability are thereby promoted. Equity reaches only certain crystallized situations of fact. The declaration reaches all situations. 